Haya: The Saudi Journal of Life Sciences

Abbreviated Key Title: Haya Saudi J Life Sci ISSN 2415-623X (Print) |ISSN 2415-6221 (Online) Scholars Middle East Publishers, Dubai, United Arab Emirates Journal homepage: https://saudijournals.com/sjls

Original Research Article

\title{
Water Quality Assessment in a Less Anthropogenic Forest Stream in the Centre Region of Cameroon
}

Biram à Ngon Eric Belmond ${ }^{1,2 *}$, Foto Menbohan Samuel ${ }^{2}$, Ndjama Josephine ${ }^{1}$, Mbohou Njoya Zakari ${ }^{2}$, Mboye Blaise Rollinat $^{2,3}$, Dzavi Jean ${ }^{1,2}$, Oumar Mahamat Oumar ${ }^{1}$, Tarkang carine $^{1}$, Nyame Mbia Donald L-Or ${ }^{2}$, Mbondo Biyong Serge ${ }^{2,4}$, Ngalamou Chamberline ${ }^{2}$

${ }^{1}$ Hydrological Research Centre, Institute of Geological and Mining Research. Po Box: 4110 Yaounde, Cameroon

${ }^{2}$ Laboratories of Hydrobiology and Environment, University of Yaounde1, Faculty of Science Po Box: 812 Yaounde, Cameroon

${ }^{3}$ Laboratory of Hydrobiology and Ichthyology, Institute of Agronomic and Forestry Research, Po Box: 2246 Libreville, Gabon

${ }^{4}$ Institute of Agricultural Research for Development, P.O. Box: 77 Limbe, Cameroon

DOI: $10.36348 /$ sjls.2020.v05i01.001 $\quad$ | Received: 11.01.2020 | Accepted: 18.01 .2020 | Published: 30.01 .2020

*Corresponding author: Biram à Ngon Eric Belmond

Email: birame.eric@yahoo.fr

\section{Abstract}

A study was carried out in a less anthropogenic forest stream, the Abouda stream, an affluent of Nga stream in the Mefou watershed, to evaluate the health status of this lotic hydrosystem. Physico-chemical analysis showed that the water is slightly acidic, well oxygenated and poor in suspended solids, conditions which are favourable for a better development of benthic macroinvertebrates. Significant differences of dissolved oxygen, ammonium and phosphates were recorded. Benthic macroinvertebrates were sampled using the multi-habitat approach and the biological results revealed a total of 1951 individuals belonging to 5 phyla, 6 classes, 15 orders, 74 families, and 79 species. Most of the organisms sampled belonged to the phylum of Arthropoda, the class of Insecta and the order of Hemiptera. The Hierarchical Ascending Classification (HAC) showed a high similarity between stations Abouda 1 (A1) and Abouda 3 (A3). Furthermore, the Multiple Correspondence Analysis (MCA), which gives the level of affinity between physico-chemical and biological variables, divided the stations between groups according to their affinities. The diversity index of Shannon and Weaver and the equitability index of Piélou showed that, stations A2 and A3 are more diversified and therefore favourable to a better development of benthic macroinvertebrates. This high diversity is confirmed by Sörensen's similarity coefficient whose values are above $60 \%$ indicated a high resemblance between stations A2 and A3.

Keywords: Water quality; Physico-chemical variables, benthic macroinvertebrates, Abouda stream, Cameroon.

Copyright @ 2020: This is an open-access article distributed under the terms of the Creative Commons Attribution license which permits unrestricted use, distribution, and reproduction in any medium for non-commercial use (NonCommercial, or CC-BY-NC) provided the original author and source are credited.

\section{INTRODUCTION}

The maintenance of continental water quality appears to be a major preoccupation for the companies which have to contribute greatly for water supply in both quantitative and qualitative aspects. The study of aquatic ecosystems and their running are more and more required for an enduring control of water resources. In the United States of America and in Europe, biological control is an important indicator for the programs in charge of controlling water quality [1]. However, studies have shown temporal fluctuations of invertebrate community linked to climate change, mainly due to a decrease in sensitive taxa gradually replaced by tolerant taxa. This permanent follow-up has permitted to measure the effects of perturbation on biological communities [2], which aimed at preserving the biodiversity by protecting natural habitat. In fact, aquatic organisms are subjected to different types of environmental stress which is produced at variable temperatures [3], enabling to obtain a more specific structure of the integrity of the ecosystem $[4,5]$, with benthic macroinvertebrates care commonly used as excellent bioindicators in the evaluation of impacts [6]. In Cameroon, benthic macroinvertebrate population is still not well understood despite the few studies already carried out in lentic and lotic watersheds notably by [7, $3,8]$.

The results revealed that, the urban water courses are subjected to organic and industrial pollution of anthropogenic origin consecutively with high population density in the watershed. This has led to a great reduction of benthic macrofauna biodiversity, with a predominance of polluo resistant groups. Studies conducted in streams of forest zones, deprived from 
anthropogenic activities with a more diversified macroinvertebrates fauna $[7,8,3]$, are therefore necessary in order to have referential data which could serve in evaluating the health status of Cameroonian watercourses. The present study aims to serve as a contribution to the knowledge of the structure of benthic macroinvertebrates of forest watercourses in Cameroon. therefore necessary in order to have referential data which could serve in evaluating the health status of Cameroonian watercourses. The present study aims to serve as a contribution to the knowledge of the structure of benthic macroinvertebrates of forests watercourse of Cameroon.

\section{MATERIAL AND METHODS \\ Description of the Sampling Sites}

This study was conducted in the Centre-South forest region of Cameroon, located between $3^{\circ} 30^{\prime}$ $3^{\circ} 58^{\prime}$ of latitude Nord and $11^{\circ} 20^{\prime}-11^{\circ} 40^{\prime}$ of longitude East. The average altitude is close to $750 \mathrm{~m}$, the relief is globally accidental, and the urban area extends on many hills of $25 \mathrm{~m}$ to $50 \mathrm{~m}$ below the plateau. This region is dominated by an equatorial climate of a specific type, known as "the Yaoundeen Climate", characterized by moderate precipitations $(1576 \mathrm{~mm} /$ year $)$ varying between $1500 \mathrm{~mm}$ and $1700 \mathrm{~mm}$ per year. The average atmospheric temperature is $23.5^{\circ} \mathrm{C}$. The soil is made up of more or less tiny quartzo-feldspathic materials, with acidic $\mathrm{pH}$ that varies between 4.5- 5.5 in the superficial layers. Four unequal seasons which vary from one year to another are observed: a long dry season (midNovember to mid-March), a small rainy season (midMarch to the end of June), a small dry season (July to mid-August) and a long rainy season (mid-August to mid-November). The vegetation is of secondary dense forest type and the river basin is dense with different streams flowing towards the Nyong river. Abouda stream, with $7.36 \mathrm{Km}$ length, is one of the main right tributary of Nga stream. Its watershed covers a surface area of about $14250 \mathrm{~m}^{2}$ located between $3^{\circ} 50^{\prime}-3^{\circ} 52^{\prime}$ of latitude Nord and $11^{\circ} 25^{\prime}-11^{\circ} 27^{\prime}$ of longitude East spreading partially over Mfoundi, Mefou and Akono divisions [10]. Samples were collected bimonthly in the morning (every $1^{\text {st }}$ and $14^{\text {th }}$ between 8 and 10 a.m.) from March to August 2016, during 12 campaigns. Three sampling stations were selected according to their position and representativeness: Abouda 1 (A1), Abouda 2 (A2) and Abouda 3 (A 3) (Fig.1).

Abouda $1 \quad\left(03^{\circ} 50^{\prime} 13.8^{\prime}{ }^{\prime} \mathrm{N}\right.$ and $\left.011^{\circ} 25^{\prime} 12.6^{\prime \prime} \mathrm{E}\right)$, with an altitude of $753 \mathrm{~m}$, is located upstream at about $300 \mathrm{~m}$ from Mount Djokye where it takes its source. The surrounding vegetation is partially dense with trees that form a sort of canopy which keeps the temperature of the station very low. The vegetation is dominated by the species Axonopus compressus. The stream-bed is sandy and measures a width of $1.8 \mathrm{~m}$, with a water flow rate of $0.33 \mathrm{~m} / \mathrm{s}$.

Abouda $2\left(03^{\circ} 50^{\prime} 47.8^{\prime \prime} \mathrm{N}\right.$ and $\left.03^{\circ} 25^{\prime} 09.0^{\prime \prime} \mathrm{E}\right)$ with an altitude of $773 \mathrm{~m}$ is located midstream, at about $1800 \mathrm{~m}$ from A1. In addition to the canopy, the vegetation is abundant dominated by the species Sida acuta. The bed is muddy with a width of $2.5 \mathrm{~m}$ and an average water flow rate of $3.12 \mathrm{~m} / \mathrm{s}$.

Abouda $3\left(03^{\circ} 51^{\prime} 48.0^{\prime \prime} \mathrm{N}\right.$ and $\left.011^{\circ} 25^{\prime} 01.9^{\prime \prime} \mathrm{E}\right)$ with its $729 \mathrm{~m}$ height is situated downstream, at about $1800 \mathrm{~m}$ from A2 and at $700 \mathrm{~m}$ from the confluent with Nga stream. The canopy generates permanent dampness and slight darkness. The surrounding vegetation is dominated by Commelina bengalensis maximum. The bed is sandy with a width of $3.2 \mathrm{~m}$ and an average water flow rate of $0.24 \mathrm{~m} / \mathrm{s}$.

\section{Physico-chemical parameters}

Physico-chemical parameters were measured at bimonthly interval at different sampling points according to $[11,12]$. Temperature $\left({ }^{\circ} \mathrm{C}\right), \mathrm{pH}(\mathrm{CU})$, conductivity $(\mu \mathrm{S} / \mathrm{cm})$ and dissolved oxygen $(\%)$ were measured in situ. In the Hydrobiology and Environment laboratory of the University of Yaoundé I, phosphates, nitrates, ammonium, suspended solids and turbidity values were determined by colorimetry using $\mathrm{HACH}$ DR/2800 while oxydability was measured by volumetry. The results were respectively expressed in $\mathrm{mg} / \mathrm{L}$ and in FTU. 


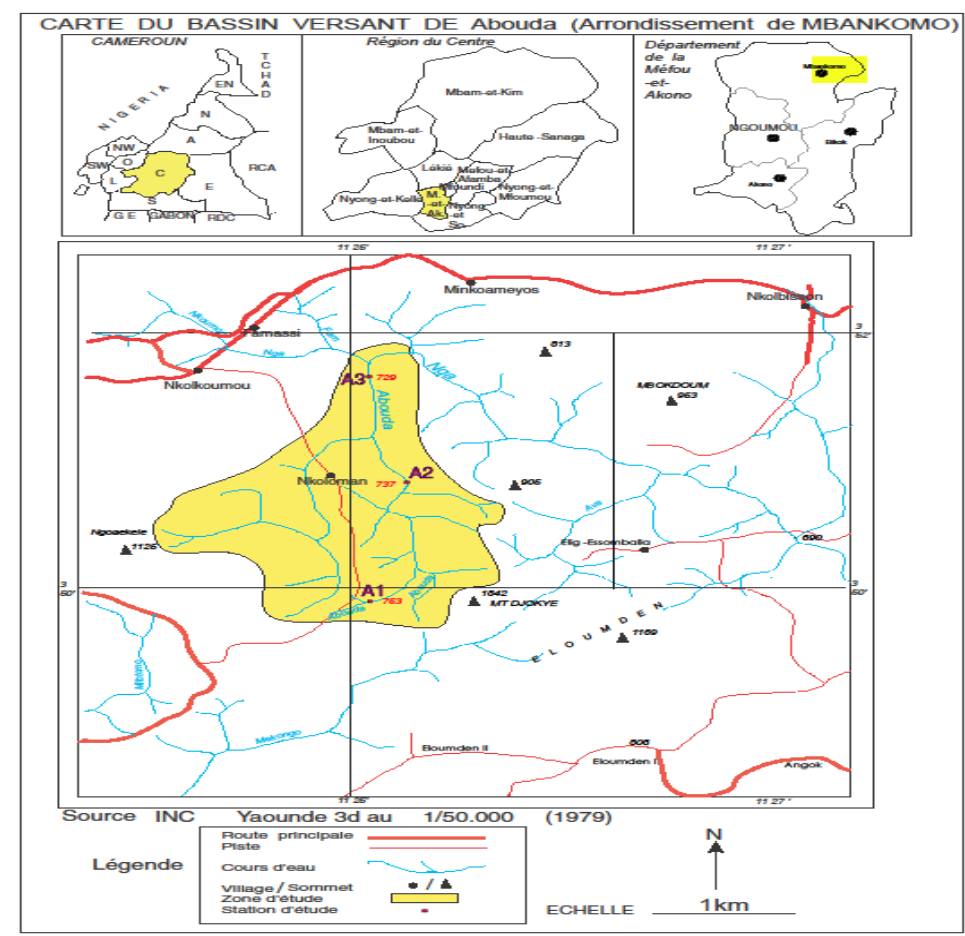

Fig-1: Hydrographic map of the study areas showing sampling stations

\section{Sampling of benthic macroinvertebrates}

Macroinvertebrates were collected using a $30 \mathrm{x}$ $30 \mathrm{~cm}$ kick-net with a $400 \mu \mathrm{m}$ mesh size. Care was taken to include all possible habitats over representative sections of the stream (100m long), according to multihabitat sampling procedure proposed by [13]. The organisms collected were put in polyethylene tubes containing $10 \%$ formalin. In the laboratory, the organisms were washed with water, handpicked from samples and preserved in $70 \%$ alcohol for subsequent counting and identification up to the family level using a stereoscopic microscope Wild M 5. The identification keys of $[14,15,16,6]$ were used.

\section{STATISTICAL TREATMENT}

The non-parametric analysis of variance test (Kruskal-Wallis) and Mann Withney test were used to compare the spatio-temporal variation of the physicochemical parameters values and the mean abundance of the different macroinvertebrate families. The Spearman correlation coefficient was used to determine the link between physico-chemical variables on the one hand, and biological variables on the other hand. The diversity index of Shannon and Weaver and the equitability index of Piélou were used to evaluate the diversity of different taxa and the repartition of species. The level of affinity between stations, physico-chemical and biological variables was appreciated using the Multiple Correspondence Analysis (MCA). Similarity between stations was evaluated using the Hierarchical Ascending Classification (HAC). XLSTAT logistic version 2007 was used for different calculations. The level of statistical significance was maintained at $95 \%$ $(\mathrm{P}<0.05)$.

\section{RESULTS}

\section{Physico-chemical results}

During this study, the temperature of water varied slightly with values situated between $21.5^{\circ} \mathrm{C}$ (Station A1 in August) and $24^{\circ} \mathrm{C}$ (Station A3) in April (Fig. 2A). The average temperature was 22,72 \pm $0,17^{\circ} \mathrm{C}$ with a thermal amplitude of $3.5^{\circ} \mathrm{C}$.

The values of suspended solids increased from upstream to downstream with values fluctuating between $6.5 \mathrm{mg} / \mathrm{L}$ (Station A1 in March) and $20 \mathrm{mg} / \mathrm{L}$ (Station A3) in July (fig. 2B). The average value is $12,53 \pm 1,98 \mathrm{mg} / \mathrm{L}$.

Turbidity increased slightly from values of 7FTU at station A2 in May to 23,5FTU at station A3 in July, with an average value of 14,52 \pm 1,83FTU (Fig. 2C).

The values of nitrates (Figure 2D) varied from $0.01 \mathrm{mg} / \mathrm{L}$ at station A2 in March to $1.4 \mathrm{mg} / \mathrm{L}$ at station A2 in April with an average value of $0.533 \pm 0.49 \mathrm{mg} / \mathrm{L}$.

From the above parameters, no significant difference was observed between the values of the from one station to another and from one month to another $(\mathrm{P}$ $>0.05)$. 


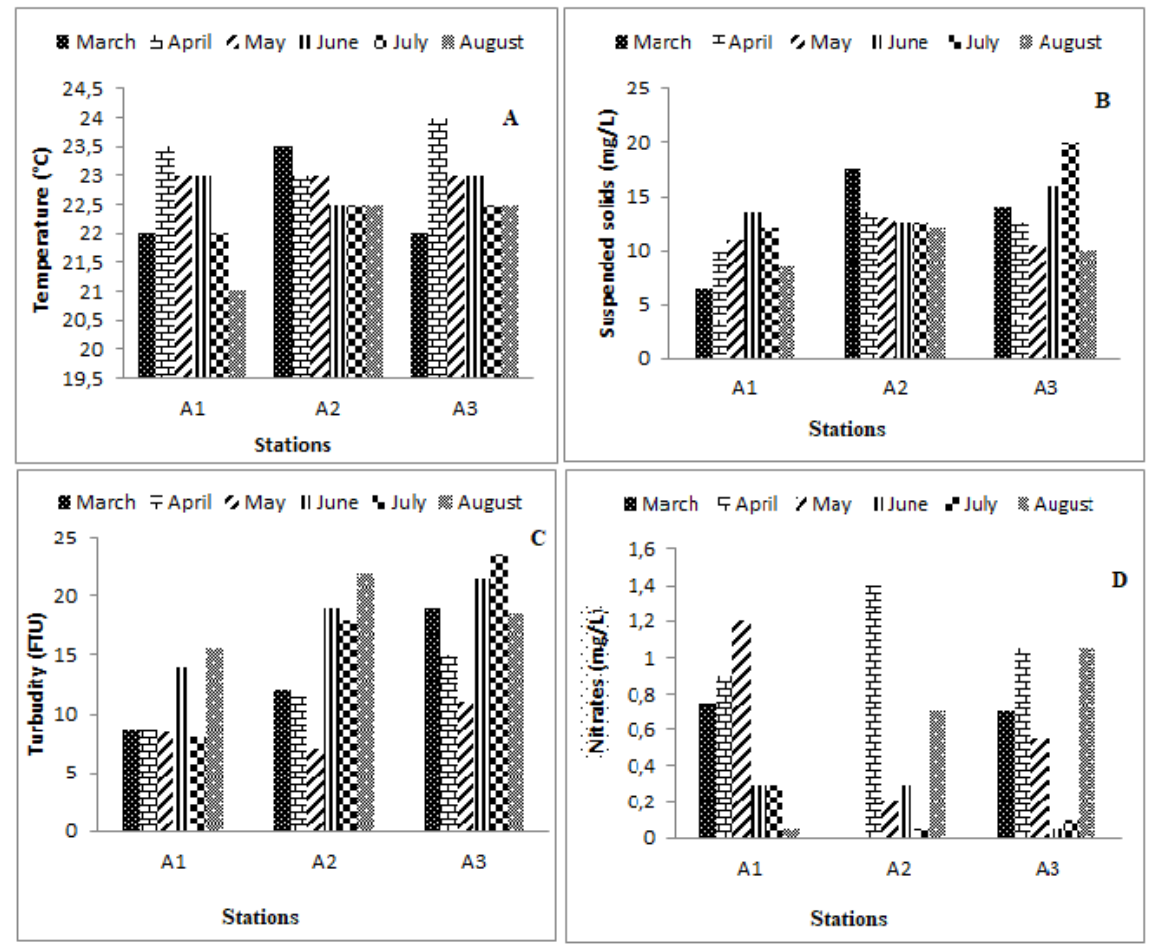

Fig-2: Spatial variations of Temperature (A), Suspended solids (B), Turbidity (C) and Nitrates (D) during the study period

A significant difference was observed for dissolved oxygen $(r=0.013 ; \mathrm{P}=0.05)$ between the different months with high values recorded in May at A2 (61.4\%) and in July at A3 (96.35\%) (Fig. 3A), and Oxydability $(\mathrm{r}=0.015 ; \mathrm{P}=0.05)$ with values situated between $0.15 \mathrm{mg} / \mathrm{L}$ (stations $\mathrm{A} 1$ and $\mathrm{A} 2$ in May) and 4.15mg/L (station A2 in March) (Fig. 3B).

The ammonium (Fig. 3C) and phosphates values (Fig. 3D) varied respectively and significantly $(\mathrm{r}$ $=0,006, p=0,05 ; r=0,02, p=0,05)$, between different stations and months from $0.1 \mathrm{mg} / \mathrm{L}$ (station $\mathrm{A} 1$ in
August) to $0.83 \mathrm{mg} / \mathrm{L}$ (station A1 in April), and from $0.34 \mathrm{mg} / \mathrm{L}$ (station A3 in May) to $2.71 \mathrm{mg} / \mathrm{L}$ (station A3 in March).

Electrical conductivity (Fig. 3E) and pH (Fig. $3 \mathrm{~F}$ ) varied respectively from $29.7 \mu \mathrm{S} / \mathrm{cm}$ (station A3 in May) to $39.6 \mu \mathrm{S} / \mathrm{cm}$ (station A1 in April) and from 5.57UC (station A1 July) to 6.83UC (station A1 April). Significant differences were observed from one station and one month to another $(\mathrm{r}=0,006 ; 0,02 ; 0,021$; $0,011 ; \mathrm{p}=0,05)$.

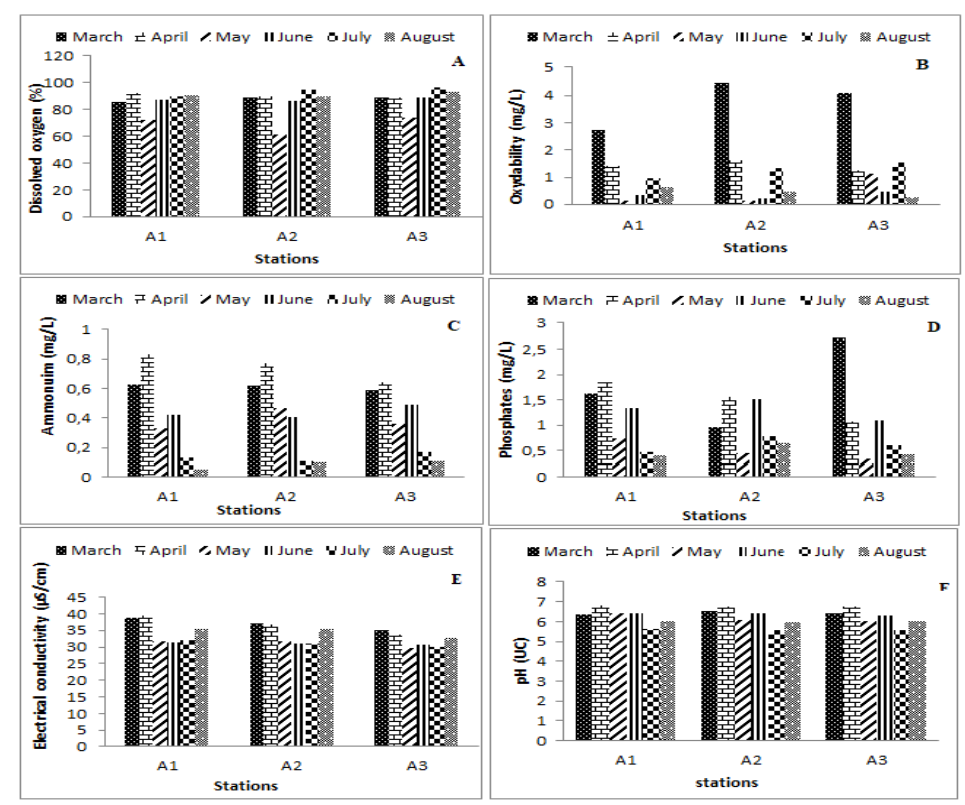

Fig-3: Spatial variations of Dissolved oxygen (A), Oxydability (B), Ammonium (C), Phosphates (D), Electrical conductivity (E) and pH (F) during the study period 


\section{Benthic macroinvertebrates}

A total of 36 campaigns were realized for 1951 organisms collected belonging to the phylum of Arthropoda (99,33\%), Mollusca $(0,05 \%)$, Annelida $(0,26 \%)$, Plathelminths $(0,26 \%)$ and Nemathelminths $(0,1 \%)$. All these organisms were distributed under 6 classes, 15 orders, 74 families and 79 species. The class of Hexapoda dominated with 9 orders, 68 families representing a relative abundance of 1595 individuals $(81.75 \%)$, followed by the class of Crustaceans $(35.41 \%)$ with 1 order, 2 families and 348 individuals $(17.84 \%)$. The classes of Oligochaeta, Acheta,
Gastropoda, and Gordiaca were the least represented. Among the 15 orders identified, Hemiptera dominated with a relative abundance of 496 individuals (25.42\%), followed by Decapoda (348 individuals: 17.84\%), Coleoptera (318 individuals: 16.30\%) and Trichoptera (227 individuals: 11.64\%). The remaining orders (Ephemeroptera, Odonata, Dictyoptera, Plecoptera and Diptera) were the least represented while organisms that were collected in a sporadic manner were grouped under « others » representing 13 individuals (0.67\%) (Fig. 4).

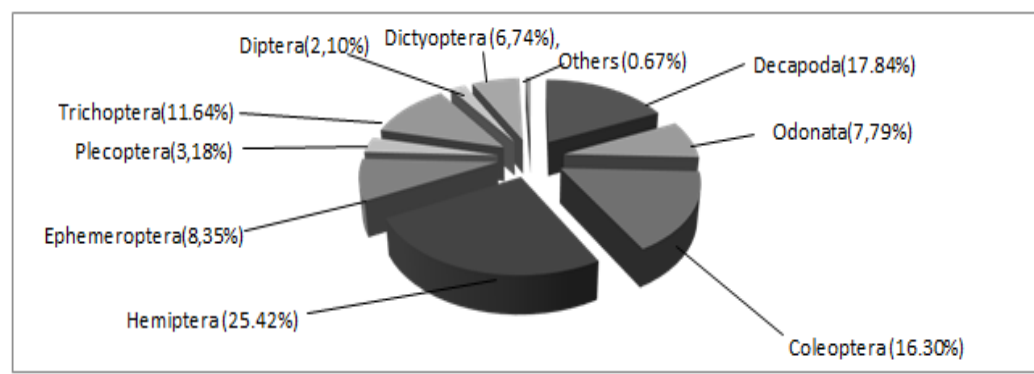

Fig- 4: Relative abundance of the different orders of benthic macroinvertebrates recorded during the study period

\section{Taxonomic Richness, EPT Index and EPT/Chironomidae Density Ratio}

Following a spatial schedule, the taxonomic richness of benthic macroinvertebrates varies between 46 families (station A1) and 60 families (station A3), showing increasing values from upstream to downstream, although, significant differences have not been found from one station to another $(\mathrm{P}>0,05)$. Concerning the EPT Index, the values oscillate between
20 families at stations (A1 and A2) and 25 families at station (A3) with the highest value obtained downstream. Significant differences were not found between values from one station to another $(\mathrm{P}>0,05)$. Regarding the EPT/Chironomidae density ratio, values decreased from upstream (126.27 at station A1) to downstream (17.32 at station A3), with a mean value of $62.85 \pm 46.24$ (Table 2). However, no significant difference was found between values.

Table-2: Spartial variation of taxonomic richness, EPT index and EPT/Chronomidae density ratio

\begin{tabular}{|c|c|c|c|c|}
\hline \multirow{2}{*}{ Indicators } & \multicolumn{3}{|c|}{ Samplings stations } & \\
\cline { 2 - 5 } & $\mathbf{A}_{\mathbf{1}}$ & $\mathbf{A}_{\mathbf{2}}$ & $\mathbf{A}_{\mathbf{3}}$ & Means and standars deviation \\
\hline Number of famillies & 46 & 51 & 60 & $52.33 \pm 7.09$ \\
\hline EPT index & 20 & 20 & 25 & $21.67 \pm 2.88$ \\
\hline EPT/Chironomidae density ratio & 126.27 & 44.95 & 17.32 & $62.85 \pm 46.24$ \\
\hline
\end{tabular}

\section{Shannon and Weaver index (H') and Piélou equitability index $(\mathbf{J})$ \\ The Shannon and Weaver Index (H') and} Piélou equitability Index (J) showed the same variation trend from upstream to downstream. The values increase from upstream $(3,906 \mathrm{bits}$ at station A1) to downstream $(4,96$ bits at station A3) for Shannon and Weaver Index, while those of Piélou equitability Index increased from 0,69bits at station A1 to 0,78bits at stations A2 and A3. Results of Sorensen's Index showed more similarities between stations. The evolution of these Indices at each station reflects an equilibrium between macroinvertebrate communities and their respective media.

\section{Hierarchic Ascending classiffication (HAC)}

According to the Hierarchic Ascending Classification (HAC), stations A1 and A3 were very similar to each other while station A2 had properties different from the other stations. (Fig. 5A).

Multiple Correspondences Analysis (MCA) showed three groups of affinity : Group 1, including station A1 characterized by water with high tenor of nitrates, phosphates, high $\mathrm{pH}$ values and a macrobenthic fauna, dominated by Pleidea and Blaberidae; Group 2 constituted of station A2 with high tenor of ammonium and electrical conductivity and a fauna dominated by Gomphidae and Naucoridae and, Group 3, which involved station A3 and high oxygenated water and a fauna dominated by Ephemeridae (Fig. 5B). 


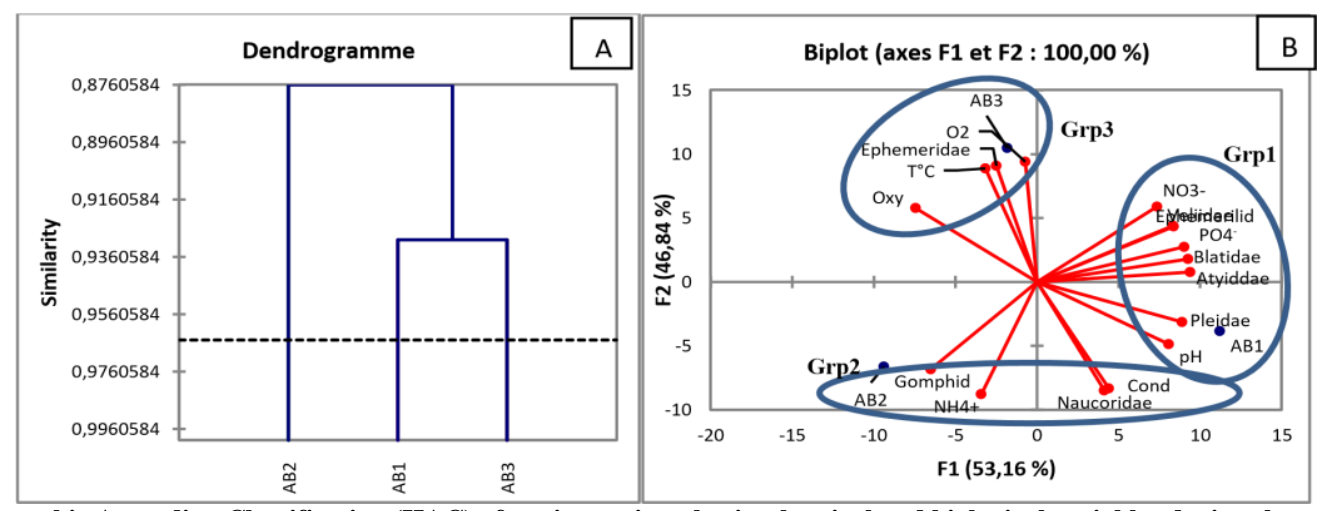

Fig- 5: A: Hierarchic Ascending Classification (HAC) of stations using physicochemical and biological variables during the study period; B: Multiple Correspondences Analysis (MCA) using environmental and biological variables during the study period.

Results of Spearman correlation test showed a positive correlation between some physico-chemical variables on the one hand and between physicochemical variables and some benthic macroinvertebrates families on the other hand. Thus, a positive and significant correlation was observed between nitrites and TDS $(r=0.819 ; \mathrm{p}=0.01)$. Also, temperature correlated with Siphloneuridae $(\mathrm{r}=0.663$; $\mathrm{p}=0.01), \mathrm{CO}_{2}$ with Pleidae $(\mathrm{r}=0.603 ; \mathrm{p}=0.01)$ and dissolved $\mathrm{O}_{2}$ with Atyidae $(\mathrm{r}=0.666 ; \mathrm{p}=0.01)$.

\section{DISCUSSION}

\section{Physico-chemical variables}

Low values of temperature recorded during the whole study period in all stations could be due to the microclimate created by the canopy which reduces light rays considerably from reaching the water surface $[17$, $3,18]$. These low values have been observed in Mefou and Nga streams belonging to the same ecological zone by $[19,8]$, and could be considered as forest stream characteristics $[3,18]$. The $\mathrm{pH}$ values were almost acidic and similar to the results obtained in Nga and Konglo streams $[8,19]$. These values reflect the acid nature of the soil in Yaoundé [21]. The dissolved oxygen values remain higher than $50 \%$ during the study period in all stations. Similar results were obtained in some forest streams as Nsapè in Douala [9] and Mefou and Nga in Yaoundé $[19,8]$. This high water saturation rate is different from the results obtained in Mfoundi, where the mean saturation rate was $25 \%$ [22]. According to $[23,8]$, the high dissolved oxygen rate in water could reflect the development of Atyidae and semi-aquatic Blaberidea and the production of potable water in case of acceptable rate. The low values of dissolved ions $\left(\mathrm{NO}_{3}{ }^{-}, \mathrm{NH}_{4}{ }^{+}, \mathrm{PO}_{4}{ }^{3-}\right)$ and oxydability obtained could be linked to low mineralization of water and low content of organic matters in water, indicating the good health status of the Abouda stream. These results confirm those obtained in periurban streams such as Nsapè [9] and Konglo [20].

High taxonomic richness of benthic macroinvertebrates was recorded in Abouda stream compared to low values obtained in the Mfoundi watershed [22], dominated by Arthropoda (99,33\%).
However, the results were similar to those obtained by $[8,18]$, reflecting a light degradation of water quality of Abouda stream. Similarly, the predominance and the large diversity of insects could explain the less anthropogenic character of river basin and the good health status of the water. The likeness of taxonomic richness of these streams could be linked to the similarity of their microhabitats. According to [2,15], majority of aquatic insects are very sensitive to pollution and/or modification of habitats and are thus the first organisms to disappear in a perturbated environment. Also, the order of Trichoptera which is known as one of the most sensitive taxon to pollution [14], presents a high taxonomical richness in this stream, similar to the results obtained in the Nga stream [8]. Plecoptera which constitute the most sensitive faunistic group to pollution [2] were also well represented, confirming the less anthropogenic character of Abouda stream. Nevertheless, the episodical presence and less abundance of Molluscs and Annelids could be a sign of low pollution. Based on the observations of $[2,15]$, in polluted hydrosytems, the benthic macrofauna is highly dominated by saprophilic and saprobiontic taxa such as Physidae, Hydrobiidae, Tubificidae and Chironomidae. The predominance of Atyidae (crustacean) and Blaberidea (semi-aquatic Dictyoptera ) could be attributed to the high oxygenated level of water and corroborate the conclusion of [3]. According to $[3,8]$, fresh water Decapoda Crustaceans and semi-aquatic Dictyoptera proliferate in media rich in oxygen and are very sensitive to low rate of dissolved oxygen in water, which generally cause their disappearance. Studies conducted in a periurban stream showed that the diversity index increased from upstream to downstream [19], revealing the normal functioning of a less anthropogenic lotic hydrosystem basin.

Multiple Correspondence Analysis (MCA) results showed that stations $\mathrm{A} 1$ and $\mathrm{A} 3$ are accommodated at polluo-sensitive taxa (Ephemeridae, Atyidea and Blaberidea) which is fond of fresh and well oxygenated water, while station A2 prefers polluotolerant taxa (Gomphidae and Naucoridae). This observation is in the same line with Hierarchic 
Ascending Classification (HAC) which reveals high similarity between stations A1 and A3.

\section{CONCLUSION}

Low values of temperature recorded during the whole study period in all stations could be due to the microclimate created by the canopy which reduces light rays considerably from reaching the water surface $[17$, $3,18]$. These low values have been observed in Mefou and Nga streams belonging to the same ecological zone by $[19,8]$, and could be considered as forest stream characteristics $[3,18]$. The $\mathrm{pH}$ values were almost acidic and similar to the results obtained in Nga and Konglo streams $[8,19]$. These values reflect the acid nature of the soil in Yaoundé [21]. The dissolved oxygen values remain higher than $50 \%$ during the study period in all stations. Similar results were obtained in some forest streams as Nsapè in Douala [9] and Mefou and Nga in Yaoundé $[19,8]$. This high water saturation rate is different from the results obtained in Mfoundi, where the mean saturation rate was $25 \%$ [22]. According to $[23,8]$, the high dissolved oxygen rate in water could reflect the development of Atyidae and semi-aquatic Blaberidea and the production of potable water in case of acceptable rate. The low values of dissolved ions $\left(\mathrm{NO}_{3}^{-}, \mathrm{NH}_{4}^{+}, \mathrm{PO}_{4}{ }^{3-}\right)$ and oxydability obtained could be linked to low mineralization of water and low content of organic matters in water, indicating the good health status of the Abouda stream. These results confirm those obtained in periurban streams such as Nsapè [9] and Konglo [20].

High taxonomic richness of benthic macroinvertebrates was recorded in Abouda stream compared to low values obtained in the Mfoundi watershed [22], dominated by Arthropoda (99,33\%). However, the results were similar to those obtained by $[8,18]$, reflecting a light degradation of water quality of Abouda stream. Similarly, the predominance and the large diversity of insects could explain the less anthropogenic character of river basin and the good health status of the water. The likeness of taxonomic richness of these streams could be linked to the similarity of their microhabitats. According to [2,15], majority of aquatic insects are very sensitive to pollution and/or modification of habitats and are thus the first organisms to disappear in a perturbated environment. Also, the order of Trichoptera which is known as one of the most sensitive taxon to pollution [14], presents a high taxonomical richness in this stream, similar to the results obtained in the Nga stream [8]. Plecoptera which constitute the most sensitive faunistic group to pollution [2] were also well represented, confirming the less anthropogenic character of Abouda stream. Nevertheless, the episodical presence and less abundance of Molluscs and Annelids could be a sign of low pollution. Based on the observations of $[2,15]$, in polluted hydrosytems, the benthic macrofauna is highly dominated by saprophilic and saprobiontic taxa such as Physidae, Hydrobiidae,
Tubificidae and Chironomidae. The predominance of Atyidae (crustacean) and Blaberidea (semi-aquatic Dictyoptera ) could be attributed to the high oxygenated level of water and corroborate the conclusion of [3]. According to $[3,8]$, fresh water Decapoda Crustaceans and semi-aquatic Dictyoptera proliferate in media rich in oxygen and are very sensitive to low rate of dissolved oxygen in water, which generally cause their disappearance. Studies conducted in a periurban stream showed that the diversity index increased from upstream to downstream [19], revealing the normal functioning of a less anthropogenic lotic hydrosystem basin.

Multiple Correspondence Analysis (MCA) results showed that stations $\mathrm{A} 1$ and $\mathrm{A} 3$ are accommodated at polluo-sensitive taxa (Ephemeridae, Atyidea and Blaberidea) which is fond of fresh and well oxygenated water, while station A2 prefers polluotolerant taxa (Gomphidae and Naucoridae). This observation is in the same line with Hierarchic Ascending Classification (HAC) which reveals high similarity between stations A1 and A3.

\section{REFERENCES}

1. Water Framework Directive. (2003). Overall Approach to the Classification of Ecological Status and Ecological Potential, Water Framework Directive Common Implementation Strategy Working Group 2, A Ecological Status (ECOSTAT), 28 p. et 2 annexes, [http://cwss.www.de/workshops/wfd/EcologiscalClassification-Guidance.pdf].

2. Moisan, J., \& Pelletier, L. (2008). Guide de surveillance biologique basée sur les macroinvertébrés benthiques d'eau douce du Québec - Cours d'eau peu profonds à substrat grossier. Direction de suivi de l'état de l'environnement, Ministère du Développement Durable, de l'Environnement et des Parcs, ISBN : 978-2-550-53591-1: 86 p.

3. Biram à Ngon, E. B., Foto Menbohan, S., Ndjama, J., Nyame Mbia, D-L., Mboye, B. R., \& Ajeagah, G. A. (2018). Ecological factors and Dictyoptera (Blaberidae) association - benthic macroinvertebrates, in some forest streams in the Centre region of Cameroon. International Journal of Advance Research in Biological Sciences, 5(7), 235-246.

4. Schuwirth, N., \& Reichert, P. (2012). Prévoir la présence des organismes dans les rivières. Eawag News 72, 14-17.

5. Borics, G., Varbiro, G., \& Padisak, J. (2013). Disturbance and stress: different meanings in ecological dynamics? Hydrobiologia. 711, 1-7.

6. Moisan, J., (2010). Guide d'identification des principaux Macroinvertébrés benthiques d'eau douce du Québec, 2010 - surveillance volontaire des cours peu profonds, Direction du suivi de l'état de l'environnement, Ministère du Développement 
Durable, de l'Environnement et des Parcs, ISBN13: 978-2-550-58416-2: 82.

7. Foto Menbohan, S., Koji, E., Ajeagah, G., Bilong Bilong, C.F., \& Njiné, T. (2012). Impact of dam construction on the diversity of benthic macroinvertebrates community in a periurban stream in Cameroon. International Journal of Biosciences. 2(11), 137-145.

8. Foto Menbohan, S., Tchakonté, S., AJeagah, G., Zébazé Togouet, S. H., Bilong Bilong, C.F., \& Njine, T. (2013). Water quality assessment using benthic macroinvertebrates in a periurban stream (cameroon). International Journal of Biotechnology, 2(5), 91-104.

9. Tchakonté, S., Ajeagah, G., Dramane, D., Camara, A.I., Konan, K.M., \& Ngassam P. (2014). Impact of anthropogenic activities on water quality and Freshwater Shrimps diversity and distribution in five rivers in Douala, Cameroon. Journal of Biodiversity and Environmental Sciences, 2(4): 183-194

10. Kodjo. (1998). Recherche pour la maîtrise du ruissellement pluvial à Yaoundé. Thèse de Doctorat 3eme cycle, Université de Yaoundé: 210 p.

11. Rodier, J. (1996). L'analyse de l'eau. 8e édition, dunod, Paris. $1384 \mathrm{p}$

12. American Public Health Association. (1998). Standard method for examination of water and wastewater. 20th Edn., Washington, DC, 1150.

13. Stark, J. D., Boothroyd, K. G., Harding, J. S., Maxted, J. R. \& Scarsbrook M. R. (2001). Protocols for Sampling Macroinvertebrates in Wadeable Streams. New Zealand Macroinvertebrates working group, report no. 1, rédigé par le Ministry for the Environment, Sustainable Management fund project, (5103): 57.

14. Durand, J. R., \& Leveque, C. (1981). Flore et faune aquatiques de l'Afrique Sahélo soudanienne. Tome II. Edition de l'ORSTOM, Paris: 458.

15. Tachet, H., Richoux, P., Bournaud, M. \& UsseglioPolatera P. (2006). Invertébrés d'eau douce : systématique, biologie et écologie. CNRS édition, Paris: 588.
16. Moisan, J. (2006). Guide d'identification des principaux Macroinvertébrés benthiques d'eau douce du Québec, surveillance volontaire des cours peu profonds, Direction du suivi de l'état de l'environnement, Ministère du Développement Durable, de l'Environnement et des Parcs , 2-55048518-1 (PDF) : 82.

17. Qiu, Z. (2013). Comparative Assessment of Stormwater and Nonpoint Source Pollution Best Management Practices in Suburban Watershed Management. Water 5, 280-291.

18. Mboye, B. R., Foto Menbohan, S., Mbega, J.D., \& Biram à Ngon, E. B. (2018). Influence of the Granulometric parameters on the Diversity and Distribution of Benthic Macroinvertebrates in the Mabounié Watershed (Central West Gabon). International Journal of Advance Research in Biological Sciences, 5(7), 252-270.

19. Foto Menbohan. S., Zebaze Togouet, S. H., Nyamsi Tchatcho, N. L. \& Njine, T. (2010). Macroinvertébrés du cours d'eau Nga: Essai de Caractérisation d'un Référentiel par des Analyses Biologiques, European Journal of Scientific Research, 43(1), 96 -106.

20. Foto Menbohan, S., Dzavi, J., Kenfack Nzongang, C., \& Biram à Ngon, E.B., Ntchantcho, R. (2019). Impact of the Anthropogenic Activities on the Diversity and Structure of Benthic Macroinvertebrates in Tropical Forest Stream. International Journals of Sciences and High Technologies, 15(1), 280-29.

21. Nola, M., Njine, T., \& Tailler, R. (1999). Approche calorimétrique des eaux des nappes de la nappe phréatique superficielle de la ville de Yaoundé (Cameroun). Microbiology of Hygienic Alimentation, $31: 9-13$.

22. Foto Menbohan. S. (1989). Etude de la pollution de deux cours d'eau à Yaoundé : l'Abiergué et Mfoundi. Etude physicochimique et biologique, Thèse de Doctorat 3eme cycle, Université de Yaoundé I: 142.

23. Agence de l'Eau. (1999). Système d'évaluation de la qualité de l'eau des cours d'eau: Grilles de seuils par usage et fonction. 1(B): 23. 